\title{
New data on the genera Allanthalia Melander, Cbvalaea Papp et Földvári and Leptodromiella Tuomikoski (Diptera: Hybotidae) from the Palaearctic
}

\section{Новые сведения о родах Allantbalia Melander, Cbvalaea Papp et Földvári и Leptodromiella Tuomikoski (Diptera: Hybotidae) Палеарктики}

\author{
I.V. Shamshev ${ }^{1}$, E. Wahlberg' ${ }^{2}$ Z. Soltész ${ }^{3}$ \\ И.В. Шамшев ${ }^{1}$, Э. Вальберг ${ }^{2}$, 3. Солтежк ${ }^{3}$
}

\footnotetext{
${ }^{1}$ Zoological Institute, Russian Academy of Sciences, Universitetskaya nab. 1, St. Petersburg, 199034, Russia. E-mail: shamshev@mail.ru Зоологический институт РАН, Университетская наб. 1, С.-Петербург, 199034, Россия.

${ }^{2}$ Swedish Museum of Natural History, Box 50007, SE-10405 Stockholm, Sweden. E-mail: emma.wahlberg@nrm.se

${ }^{3}$ Hungarian Natural History Museum, 1083 Budapest, Baross u. 13., Hungary. E-mail: soltesz.zoltan@nhmus.hu
}

KEYWORDS: Diptera, Hybotidae, new synonym, distribution, Palaearctic.

КЛЮЧЕВЫЕ СЛОВА: Diptera, Нybotidae, новый синоним, распространение, Палеарктика.

ABSTRACT. New data on distribution in the Palaearctic Region for three species of flies of the family Hybotidae are provided. Allanthalia pallida (Zetterstedt, 1838) is recorded for the first time from Yakutia (Eastern Siberia) and Leptodromiella crassiseta (Tuomikoski, 1932) - from the Russian Far East (Amurskaya Province). The following new synonym is proposed: Chvalaea rugosiventris (Strobl, 1910) $=$ Chvalaea sopianae Papp et Földvári, 2002, syn.n. Chvalaea rugosiventris is recorded for the first time from Eastern Siberia (Krasnoyarskiy Territory) and from the Russian Far East (Primorskiy Territory). The latter species is redescribed and illustrated. All distributional data on these species are mapped.

РЕЗЮМЕ. Представлены новые сведения о видах трех редких в Палеарктике родов мух семейства Hybotidae. Allanthalia pallida (Zetterstedt, 1838) впервые указывается из Якутии (Восточная Сибирь), а Leptodromiella crassiseta (Tuomikoski, 1932) - с Дальнего Востока России (Амурская область). Обоснован новый синоним: Chvalaea rugosiventris (Strobl, 1910) = Chvalaea sopianae Papp et Földvári, 2002, syn.n. Chvalaea rugosiventris указывается впервые из Восточной Сибири (Красноярский край) и с Дальнего Востока России (Приморский край), вид переописан, даны его фотографии. Все данные о распространении перечисленных видов нанесены на карту.

\section{Introduction}

The Hybotidae are quite well studied taxonomically in Europe, but zoogeographical data are misleading in many cases due to insufficient knowledge of these flies from eastern parts of the Palaearctic Region [Shamshev, 2016].

Our paper reports new records of three rare hybotid genera - Allanthalia Melander, 1928, Chvalaea Papp et Földvári, 2001 and Leptodromiella Tuomikoski, 1936. Allanthalia is known from the Holarctic realm with 1 described species from the Palaearctic and 1 undescribed species from the Nearctic, Leptodromiella is restricted to the Palaearctic only with 1 described species from Europe and at least 1 undescribed species from Japan [Chvála, 1983; B.J. Sinclair, personal communication]. Chvalaea currently includes six species distributed in the Palaearctic (1) and Neotropics (5). In addition, an unclear species is present in Japan [B.J. Sinclair, personal communication] and undescribed species are known from the Oriental and Australasian Regions [Sinclair, Cumming, 2000 (as undescribed genus B); Ale-Rocha, 2006; Kahanpää, 2013; our unpublished materials from Malaysia (Pahang) and Tasmania]. Allanthalia is classified in the subfamily Oedaleinae, whereas Chvalaea and Leptodromiella are assigned to Ocydromiinae [Sinclair, Cumming, 2000, 2006].

This study is based on Hybotidae material housed in the Hungarian Natural History Museum, Budapest (HNHM), Swedish Museum of Natural History (SMNH), Zoological Institute of Russian Academy of Sciences, St. Petersburg, Russia (ZIN) and Zoological Museum of Moscow State University, Moscow, Russia (ZMMU). Dried pinned (HNHM, ZIN, ZMMU) and alcohol preserved (SMNH) specimens were examined. To facilitate observations, the terminalia were macerated in cold $10 \%$ $\mathrm{KOH}$, then put for a short period in $85 \%$ lactic acid and immersed in glycerine. Terms used for adult structures primarily follow those summarised by Cumming et Wood [2009]. Habitus photos were produced using a Canon 
EOS 7D with Canon $100 \mathrm{~mm}$ macrolens (Canon Inc.) connected to a motorized StackShot ${ }^{\mathrm{TM}}$ (Cognisy Inc.) automated focus rail (in SMNH). Photos of genitalia were produced or using Nikon d7100 + Mitutoyo M Plan Apo5X / 0.14 objective (in HNHM), or with manual focus stacking, using a Nikon DS-Fil camera attached to a Nikon Eclipse 80 i microscope (Nikon Corp.) (in SMNH). Both habitus and genitalia photos were aligned and stacked in Zerene Stacker 1.04 (Zerene Systems LCC).

\section{Taxonomic account}

Class Insecta Linnaeus, 1758

Order Diptera Linnaeus, 1758

Suborder Brachycera Macquart, 1834

Superfamily Empidoidea Latreille, 1804

Family Hybotidae Meigen, 1820

Genus Allanthalia Melander, 1928

Type species: Anthalia pallida Zetterstedt, 1838 (by original designation)

\section{Allanthalia pallida (Zetterstedt, 1838)}

Fig. 14.

MATERIAL EXAMINED. RUSSIA: $1+$, Yakutia, Indigirka River, mouth of In'yali River [ 65 $\left.15^{\circ} \mathrm{N} 143^{\circ} 09^{\prime} \mathrm{E}\right]$ (ZMMU). SWEDEN: Hs. Hudiksvalls kommun, Stensjön-Lomtjärn, Stensjön, marsh pine forest close to bog, 62.140333, 16.286100 (=Trap ID 43), 2005.vi.15-2005.vi.29 (=coll. event ID 1907), Leg. Swedish Malaise Trap Project (SMNH), Allanthalia pallida; Up. Älvkarleby kommun, Båtfors, pine forest with blueberry, 60.46065, 17.317817 (=trap ID 7), 2004.vi.27-2004.vii.01 (=coll. event ID 858), Leg. Swedish Malaise Trap Project (SMNH), Allanthalia pallida (SMNH).

DISTRIBUTION. PALAEARCTIC. Europe: Austria, Czech Republic, Finland, Germany, Norway, Russia (Karelia, Murmanskaya Province, Yakutia), Slovakia, Sweden, Switzerland. Type locality: Lycksele lappmark ("Lapponia Umensi, Lycksele") (Sweden).

REMARKS. Allanthalia pallida is recorded here for the first time from Yakutia (Eastern Siberia of Russia). Also, we provide here two additional records from Sweden where this species has been known after single locality [Chvála, 1983].

Genus Chvalaea Papp et Földvári, 2002

Type species: Leptopeza rugosiventris Strobl, 1910 (by original designation)

\section{Chvalaea rugosiventris (Strobl, 1910)}

$$
\text { Figs 1-11, } 14 .
$$

Leptopeza rugosiventris Strob1, 1910: 73 ( $\odot$ — mistake, actually $\mathrm{O}^{7}$ ). Type locality: Forest of Kematen, near Admont ("Im Kematenwalde bei Admont") (Austria).

Chvalaea sopianae Papp et Földvári, 2002: 356 (†), Figs 11 (habitus), 12 (wing), 13 (antenna), 15 (abdominal segment 8). Type locality: Pécs, Melegmányi-völgy (Hungary), syn. nov.

Chvalaea rugosiventris: Papp et Földvári, 2002: 356 ( mistake, actually $O^{7}$ ), Figs 14 (antenna), 16 (abdominal segment 8); Chvála, 2003: 173 (data on holotype).

Chvalaea sopianae: Kahanpää, 2013: 592 ()), Fig. 1 (habitus photo) [record from Finland]; Shamshev, 2016: 103 [records from Russia].

TYPE MATERIAL EXAMINED. Chvalaea sopianae Papp et Földvári, 2002, Holotype + , label data as in Fig. 2 (HNHM).

ADDITIONAL MATERIAL EXAMINED. HUNGARY: $1 \sigma^{7}$, label data as in Fig. 1, Chvalaea rugosiventris (Strobl) (HNHM).
RUSSIA: Krasnodarskiy Territory: $1 \sigma^{T}$, Lazarevskoe [43⒌ $\left.54^{\prime} 49^{\prime \prime} \mathrm{N} 39^{\circ} 19^{\prime} 53^{\prime \prime} \mathrm{E}\right]$, broadleaf forest, 24.ix.1982, Gorodkov; $1 \Im^{7}$, environs of Adler, $43.4789^{\circ} \mathrm{N}, 39.9067^{\circ} \mathrm{E}, 26 . x .2009$, D. Gavryushin. Krasnoyarskiy Territory, env. of Krasnoyarsk, Stolby Nature Reserve [55 $\left.53^{\prime} \mathrm{N} 92^{\circ} 46^{\prime} \mathrm{E}\right]$, 2nd Stolb, mixed forest, 600m, 18.viii.1972. Primorskiy Territory: $1 \sigma^{7}$, Sudzukhinskiy Nature Reserve [now Lozovskiy, $43^{\circ} 14^{\prime} \mathrm{N} 133^{\circ} 24^{\prime} \mathrm{E}$ ], Ta-Chingouz, 5.ix.1948, Gussakovsky; $1 \sigma^{7}$, same locality, 16.ix.1948, Gussakovsky; $10^{\prime \prime}$, Yuzhnoe Primor'e, Kievka [42 $\left.54^{\prime} 20^{\prime \prime} \mathrm{N} 133^{\circ} 42^{\prime} 06^{\prime \prime} \mathrm{E}\right]$, 4.ix.1980, A. Shatalkin; 1 \%, same locality, 7.ix.1980, A. Shatalkin;

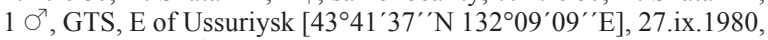
A. Shatalkin; 1 9 , Primorskiy Territory, Kedrovaya Pad' Nature

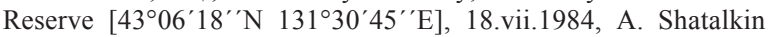
(ZMMU).

TAXONOMIC NOTES. Strobl [1910: 73] described Leptopeza rugosiventris after a single specimen and indicated mistakenly its sex as + [Chvála, 2003]. Papp and Földvári [2002: 356] misinterpreted the sex (as + ) of the only specimen of this species they recorded from Hungary. Actually, these authors re-described and illustrated the $\sigma^{7}$ of C. rugosiventris for the first time (Fig. 3). In the same paper Papp and Földvári [2002: 356] described a second Palaearctic species, Chvalaea sopianae. The sex of the holotype of $C$. sopianae was correctly recognised $(+)$ (Fig. 4). However, our material shows that features used by Papp and Földvári to distinguish $C$. rugosiventris and $C$. sopianae are sexually dimorphic characters and thus, $C$. rugosiventris and $C$. sopianae are $\sigma^{7}$ and $q$ (respectively) of one species. Consequently, Chvalaea sopianae Papp et Földvári, 2002 is proposed as a junior synonym of Leptopeza rugosiventris Strobl, 1910.

REMARKS. Chvalaea rugosiventris is the only described species of the genus known from the Palaearctic Region. It has been known for a long time only from its type locality in Austria. Papp and Földvári [2002] recorded this species from Hungary. Recently, C. rugosiventris was reported after very few specimens from Finland [Kahanpää, 2013 (as C. sopianae)] and from Krasnodarskiy Territory and Karelia of Russia [Shamshev, 2016 (as C. sopianae)]. We provide here additional records of $C$. rugosiventris from Krasnodarskiy Territory of Russia and two new records of this species from Eastern Siberia (Krasnoyarskiy Territory) and the Russian Far East (Primorskiy Territory). Also, below we re-describe the $\sigma^{7}$ of $C$. rugosiventris. The structure of segment 8 and $\sigma^{7}$ terminalia of $C$. rugosiventris are very similar to Neotropical species and agreed in all details with generic diagnosis of the postabdomen given by Ale-Rocha [2006].

Label data suggest that $C$. rugosiventris is active over a long period from the middle of June (Finland, Hungary, Russian Far East) till the end of September (Black Sea coast of the Caucasus, Russian Far East), and occasionally even till the end of October (Black Sea coast of the Caucasus, Russia).

RE-DESCRIPTION. O' (Fig. 5). Head (Fig. 7) black. Occiput faintly greyish pollinose, with short pale hair-like setae. Ocellar tubercle with 2 minute proclinate pale setae. Frons very short, narrow, faintly greyish pollinose. Eyes meeting below antennae. Antenna inserted above middle of head; brown (basal segments sometimes slightly paler); pedicel with circlet of subequally short subapical setae; postpedicel long, narrow, about 5 times longer than wide, with bristlelike terminal bare arista. Palpus small, yellow.

Thorax entirely faintly tomentose; prothoracic sclerites brown but postpronotal lobe brownish yellow; scutum extensively brown only narrow lateral space and postalar tubercle brownish yellow; scutellum brown anteriorly and paler along margin (brownish yellow viewed posteriorly); metanotum large, convex, reddish brown anteriorly and brown posteriorly; pleura yellowish brown. Postpronotal lobe with several 
minute setae. Mesonotum with 1 long black notopleural bristle, otherwise bearing minute setae, scutellum with 2 pairs of equally minute setae; acrostichals scattered, arranged in two broad rows, lacking on prescutellar depression; dorsocentrals uniserial, 2 prescutellar pairs somewhat longer.

Leg colouration: Fore coxa brown, mid coxa yellowish brown, hind coxa yellow. Femora yellow with some brownish tinge, hind femur more distinctly brownish yellow on about apical half dorsally; knees brown. Fore and mid tibiae yellow (fore tibia sometimes with brownish tinge), hind tibia extensively brown to yellowish brown, yellow near base. Fore and mid tarsi with tarsomeres 3-5 brownish, otherwise yellow; hind tarsus almost entirely brownish, only tarsomere 1 yellow near base. Hind femur somewhat thickened on about basal half; fore tibia somewhat thickened, convex on about basal half anteriorly; hind tibia thickened (except extreme base); Leg vestiture: Coxae and trochanters with numerous ordinary pale setae of different lengths. Femora covered with thin mostly pale setae of different lengths, no strong black bristles or spines; fore and mid femora with short hair-like anteroventral and posteroventral setae, also, mid femur with 1 long subapical seta anteriorly; hind femur with anteroventral and posteroventral setae becoming longer and somewhat stronger toward apex (longest subapical setae about 1.5 times as long as width of femur). Fore tibia with some longer ventral and posteroventral setae toward apex; mid tibia with 1 long thin brownish anterodorsal and 1 similar anteroventral seta on basal half; hind tibia clothed in short to moderately long, uniform thin setae. Fore tarsus covered with ordinary short setae; mid basitarsus with 1 long brownish posteroventral seta near base; hind tarsomeres 1-2 with numerous strong, rather long setae ventrally (Fig. 9), tarsomeres 3-5 with black ventral protuberances, tarsomere 4 with 2 black anterodorsal and posterodorsal subapical long spines; pulvilli lacking.

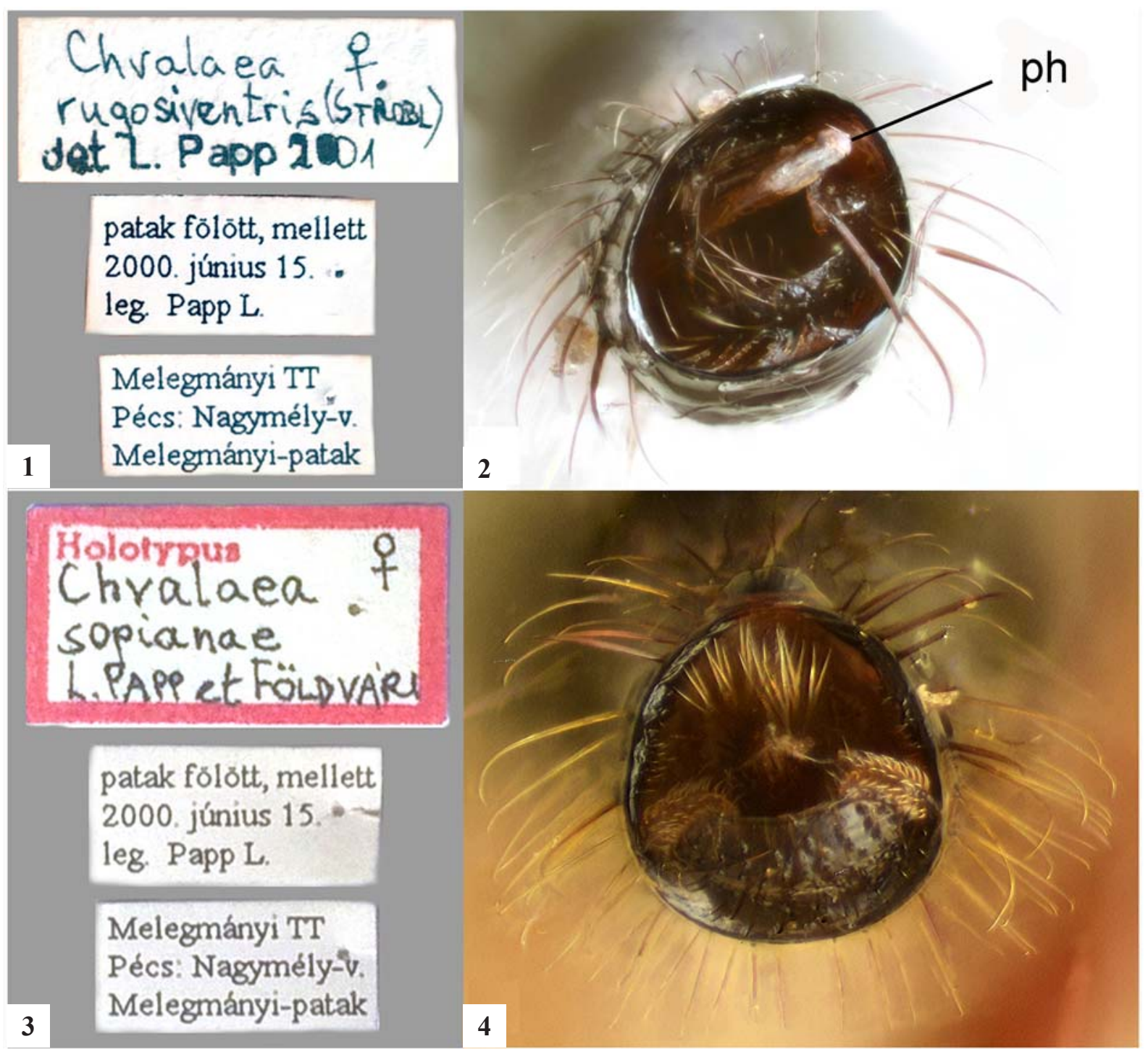

Figs 1-4. Chvalaea from the Collection of HNHM: 1,2 - C. rugosiventris; 3, 4 - C. sopianae; 1, 3 - labels data; 2, 4-abdominal segment 8 and terminalia, posterior view in situ. Abbreviations: ph - phallus.

Рис. 1-4. Chvalaea из Коллекции Венгерского музея естественной истории: $1,2-$ C. rugosiventris; $3,4-$ C. sopianae; $1,3-$ данные этикеток; $2,4-8$-й сегмент брюшка и терминалии, сзади in situ. Сокращения: ph — фаллус. 
Wing shape and venation as in Fig. 5; slightly uniformly infuscate; pterostigma indistinct. Halter yellow.

Abdomen: shiny, punctate (except segment 8), covered with numerous pale setae longer laterally (tergite 8 with brownish posteromarginal setae); segment 8 narrower and somewhat longer than segment 7 , with smooth surface, tube-like with fused tergite and sternite, slightly asymmetrical on apical part, with small circular membranous area on
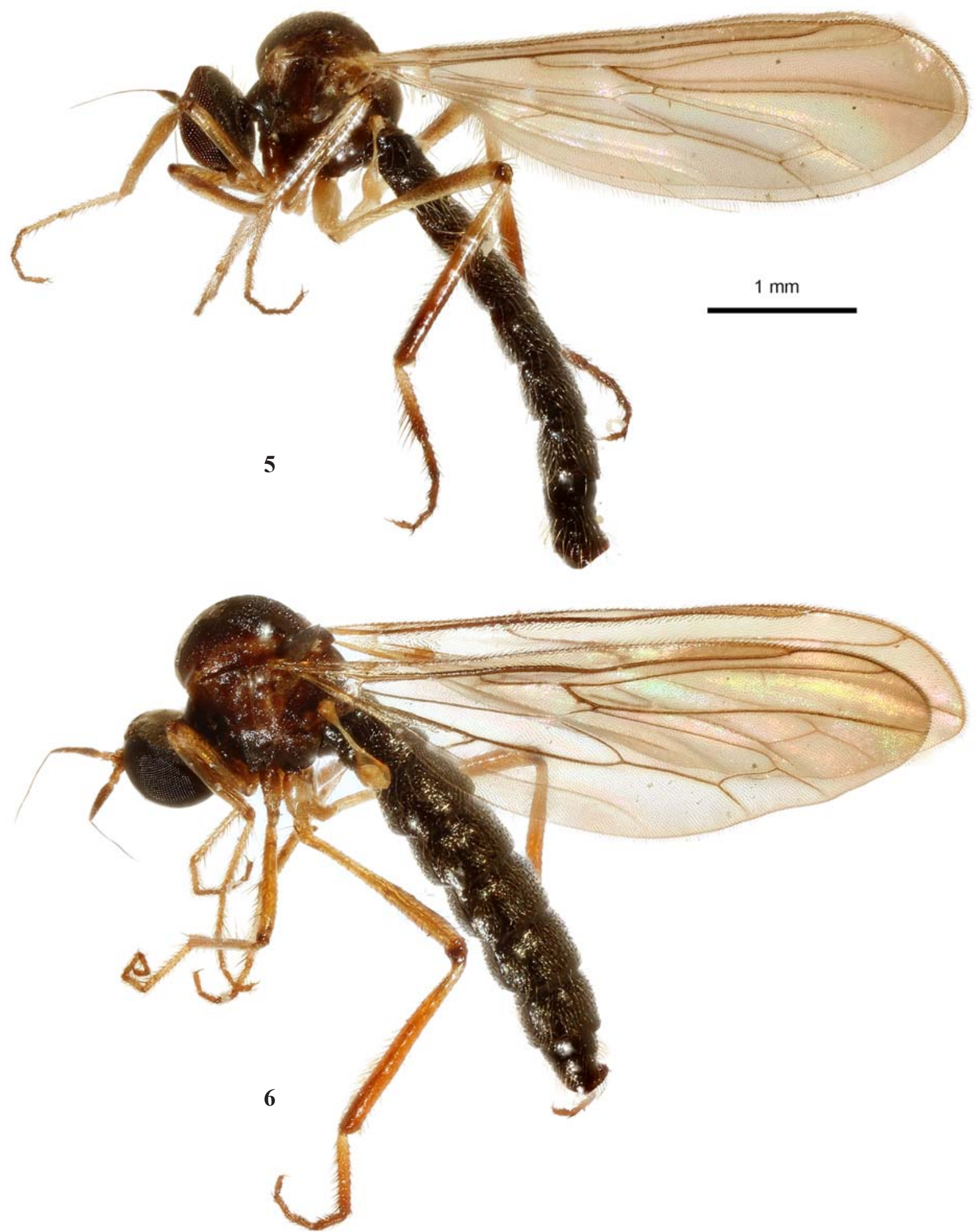

Figs 5-6. Chvalaea rugosiventris: $5-\bigcirc^{7}$ habitus, lateral view (Primorskiy Territory, Russia); $6-\uparrow$ habitus, lateral view (Primorskiy Territory, Russia).

Рис. 5-6. Chvalaea rugosiventris: 5 - габитус самца, сбоку (Приморский край, Россия); 6 - габитус самки, сбоку (Приморский край, Россия). 

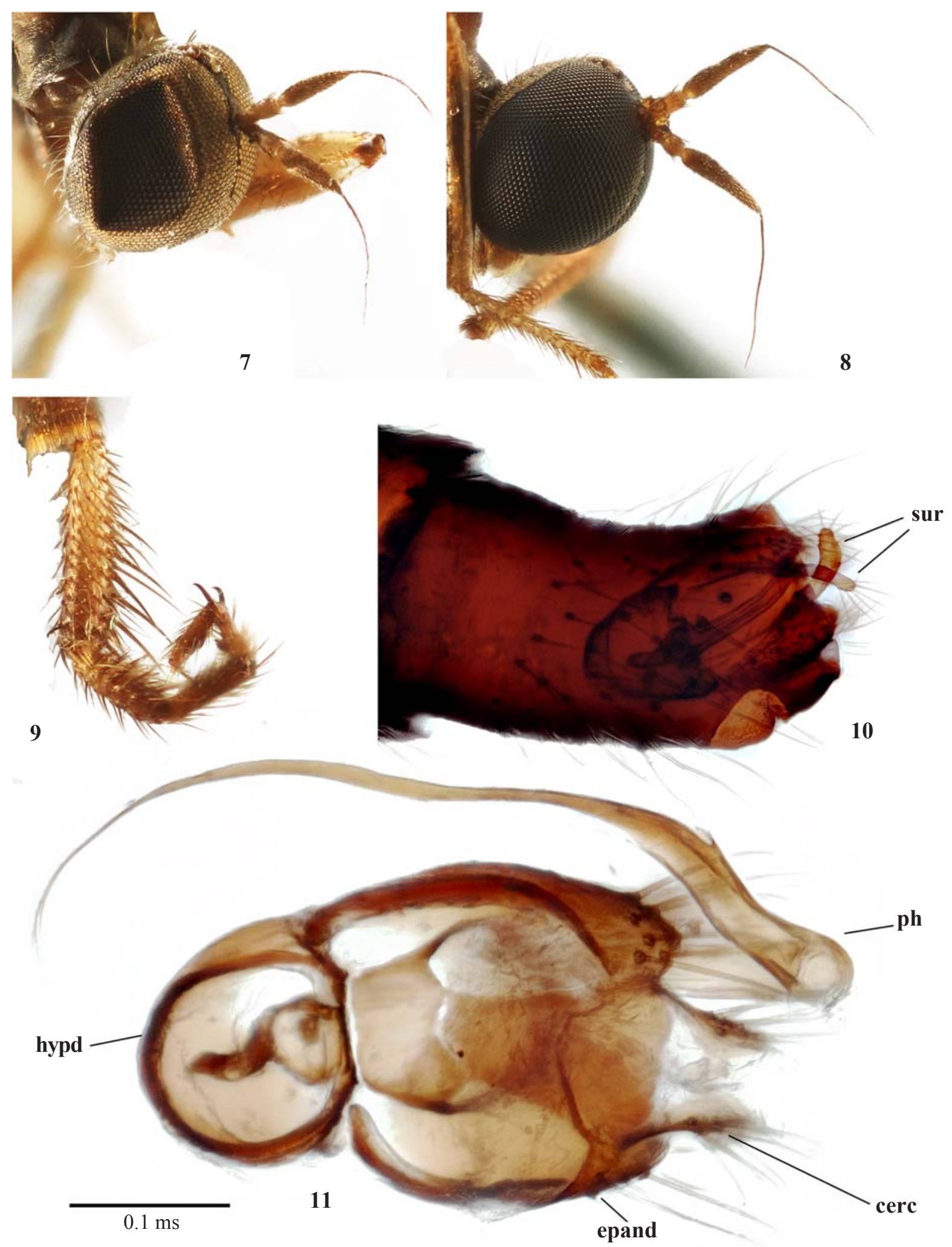

Figs 7-11. Chvalaea rugosiventris: 7 - head of $\sigma^{7}$, dorso-lateral view; 8 - head of $\circ$, dorso-lateral view; 9 - hind tarsus, postero-lateral view; 10 - abdominal tergite $8, \sigma^{7}$, lateral view; 11 - $0^{7}$ terminalia, dorsal view. Abbreviations: cerc — cercus, epand — epandrium, hypd - hypandrium, ph - phallus, sur - surstylus.

Рис. 7-11. Chvalaea rugosiventris: 7 — голова самца, дорсо-латерально; 8 - голова самки, дорсо-латерально; 9 — задняя лапка, постеро-латерально; 10 - 8-й сегмент брюшка, самец, сбоку; 11 - терминалии самца, сверху. Сокращения: сеrс — церк, ераnd — эпандрий, hypd - гипандрий, ph — фаллус, sur - сурстиль. 
ventral surface (Fig. 10). Male's terminalia (Fig. 11) entirely retracted in abdominal segment 8 ; small, rotated approximately $90^{\circ}$ to right, asymmetrical. Cerci broad ovate, of subequal shape and size, covered with numerous short ordinary setae. Epandrium deeply cleft dorsally; epandrial lamellae united dorsally by very narrow sclerotisation ending as indistinct, membranous area near left epandrial lamella, with numerous long setae. Surstyli articulated, elongate, cylindrical, ventro-dorsally directed, of subequal length, with ordinary setae, right surstylus somewhat broadened apically. Hypandrium rather short, asymmetrical, with 2 long dorsal subapical setae. Phallus elongate, biarticulated, bent inside of hypopygium; phallic shaft gradually arched, cylindrical; distiphallus expanded basally, with simple ribbon-like, long terminal appendage; basiphallus-distiphallus articulation projected outside of epandrium, visible on left side of cerci.

Female (Fig. 6). Similar to male, except the following characters: antenna longer, about 7 times longer than wide (Fig. 8); abdominal tergite 8 shorter, symmetrical, with dorsal subapical tubercle, bearing brush of several long black curved posteromarginal setae on each side; terminalia entirely retracted in segment 8 .

MEASUREMENTS. Body 4.4-4.5 mm, wing 4.0-4.4 $\mathrm{mm}$.

DISTRIBUTION. PALAEARCTIC: Austria, Finland, Hungary, Russia (Karelia, Krasnodarskiy, Krasnoyarskiy and Primorskiy Territories).

Genus Leptodromiella Tuomikoski, 1936

Type species: Oropezella crassiseta Tuomikoski, 1932 (by original designation).

\section{Leptodromiella crassiseta (Tuomikoski, 1932)} Figs 12-14.

Oropezella crassiseta Tuomikoski, 1932: 49. Type locality: Padasjoki, Vesijakaa (Ta) (Finland).

MATERIAL EXAMINED. RUSSIA: $2 \sigma^{\top} \sigma^{\top}$, Amurskaya Province, Zeya $\left[53^{\circ} 44^{\prime} 00^{\prime \prime} \mathrm{N} 127^{\circ} 15^{\prime} 00^{\prime \prime} \mathrm{E}\right], 1-5 . v i i .1978$, A. Shatalkin; 2 os, same locality, 22-24.vi.1978 (ZMMU).

DISTRIBUTION. Palaearctic: Finland, Russia (Amurskaya and Moskovskaya Provinces, Karelia), Sweden.

REMARKS. Leptodromiella crassiseta has been known only from Finland, Sweden and central part of European Russia (single record from Moskovskaya Province) [Shamshev, 2016]. Also, as far as we are aware, these are the first photographs of this species.

\section{Discussion}

Holarctic area has already been reported for the genus Allanthalia [Melander, 1928]. However, records of A. pallida from North America [e.g., Melander, 1965] are misidentifications. The genus is represented in the Nearctic by a single undescribed species [B.J. Sinclair, personal communication]. All previous records of $A$. pallida in the Palaearctic have originated from Scandinavia and Central Europe [Chvála, 1983]. Our data show that, actually, A. pallida occurs very far to the east of Eurasia (Eastern Siberia). This pattern is quite common among Palaearctic empidoids, including some species of the subfamily Oedaleinae [Shamshev, 2016]. Generally, the Oedaleinae are restricted to the Northern Hemisphere occurring only in the Palaearctic, Nearctic and in mountains of the north part of the Oriental Region. The only exception is Allanthalia that has not been recorded yet from the Oriental Region.
The genus Leptodromiella is endemic of the Palaearctic Region and this is quite unusual for the subfamily Ocydromiinae showing highest diversity, including considerable number of endemic genera, in the Southern Hemisphere (except problematic Oriental Stylocydromia Saigusa, 1986). Scattered data on distribution of L. crassiseta, including our single record from the Russian Far East, suggest that, actually, this species is very widely distributed but it may have disjunct populations.

The single Palaearctic species of the genus Chvalaea is very far outside of the centre of highest diversity of this group that is very probably the Neotropics [Ale-Rocha, 2006]. Especially in respect that Chvalaea has not yet been recorded from the Nearctic and Afrotropics. Surprisingly but closely related Oropezella Collin, 1926 shows a very similar pattern (even if the monophyly of this group is disputable). Oropezella is diverse in Neotropical and Australasian regions, but it is absent in other zoogeographical regions except the Palaearctic where the genus is represented by a single species, $O$. sphenoptera Loew, 1873. In contrast with $C$. rugosiventris, $O$. sphenoptera is a very common European species, but it has not yet been recorded in the eastern part of the Palaearctic beyond the Ural Mountains. Chvalaea rugosiventris suggests quite distinctly disjunctive pattern of distribution.

ACKNOWLEDGEMENTS. We are indebted to Andrey Ozerov (ZMMU) for the loan of specimens used in our study. Our special thanks are due to Bradley Sinclair (Canadian National Collection of Insects and Canadian Food Inspection Agency, Ottawa) for reading the manuscript, remarks and checking English. The study was performed in the frames of the Russian State Research Project no. AAAA-A17117030310210-3, the Program of RAS Presidium "Biodiversity of Natural Systems" and supported by the Russian Foundation for Basic Research (grant no. 15-04-03457) to Igor Shamshev. Emma Wahlberg is funded by a grant from The Swedish Taxonomy Initiative (dha 2014-149 4.3), that also provided financial support for Igor Shamshev to visit and work at SMNH.

\section{References}

Ale-Rocha R. 2006. First description of species of Chvalaea Papp \& Földvári from the Neotropical Region (Diptera, Hybotidae, Ocydromiinae) // Zootaxa. No.1167. P.17-30.

Chvála M. 1983. The Empidoidea (Diptera) of Fennoscandia and Denmark. II. General Part. The families Hybotidae, Atelestidae and Microphoridae// Fauna Entomologica Scandinavica. Vol.12. P.1-279.

Chvála M. 2003. Revision of the Hybotidae (Diptera) described by Gabriel Strobl from the Alps, with an annotated list of Strobl's localities and notes on the Admont Collection // Acta Universitatis Carolinae Biologica. Vol.47. P.163-186.

Cumming J.M., Wood D.M. 2009. Adult morphology and terminology // Brown B.V., Borkent A., Cumming J.M., Wood D.M., Zumbado M. (eds.), Manual of Central American Diptera. Vol.1. NRC Research Press, Ottawa. P.9-50.

Kahanpää J. 2013. First record of the genus Chvalaea Papp \& Földvári from Northern Europe (Diptera: Hybotidae) // Zootaxa. No.3716. P.592-594.

Melander A.L 1928. Diptera, Fam. Empididae // Wytsman P. (ed.). Genera Insectorum. Vol.185 (1927). 434 pp.

Melander A.L. 1965. Family Empididae (Empidae, Hybotidae) // Stone A., Sabrosky C.W., Wirth W.W., Foote R.H., Coulson J.R. (eds.). A catalog of the Diptera of America north of Mexico. United States Department of Agriculture, Agriculture Handbook 276. P.446-481. 

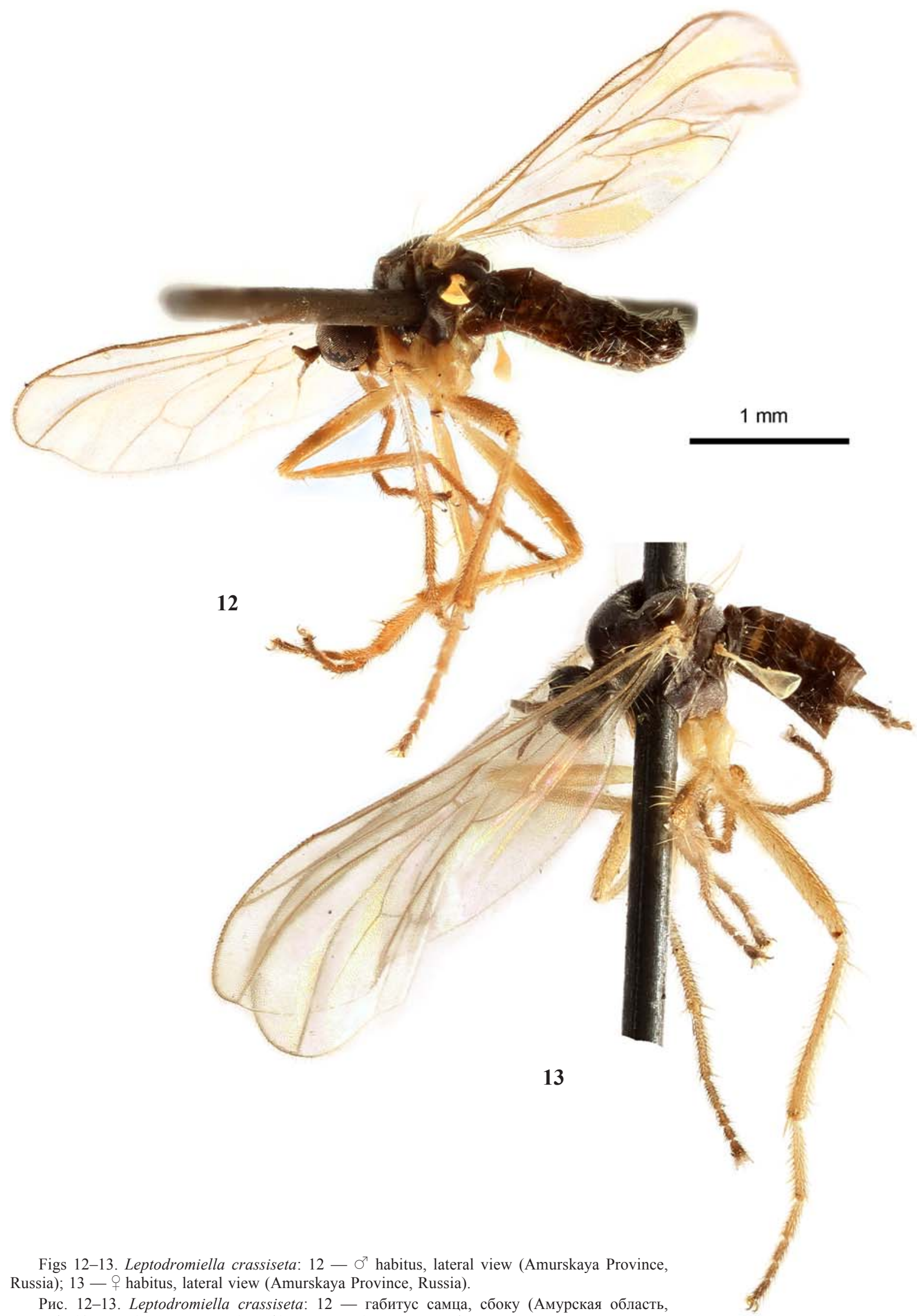

Figs 12-13. Leptodromiella crassiseta: $12-\mathrm{O}^{7}$ habitus, lateral view (Amurskaya Province, Russia); 13 - 9 habitus, lateral view (Amurskaya Province, Russia).

Рис. 12-13. Leptodromiella crassiseta: 12 - габитус самца, сбоку (Амурская область, Россия); 13 - габитус самки, сбоку (Амурская область, Россия). 


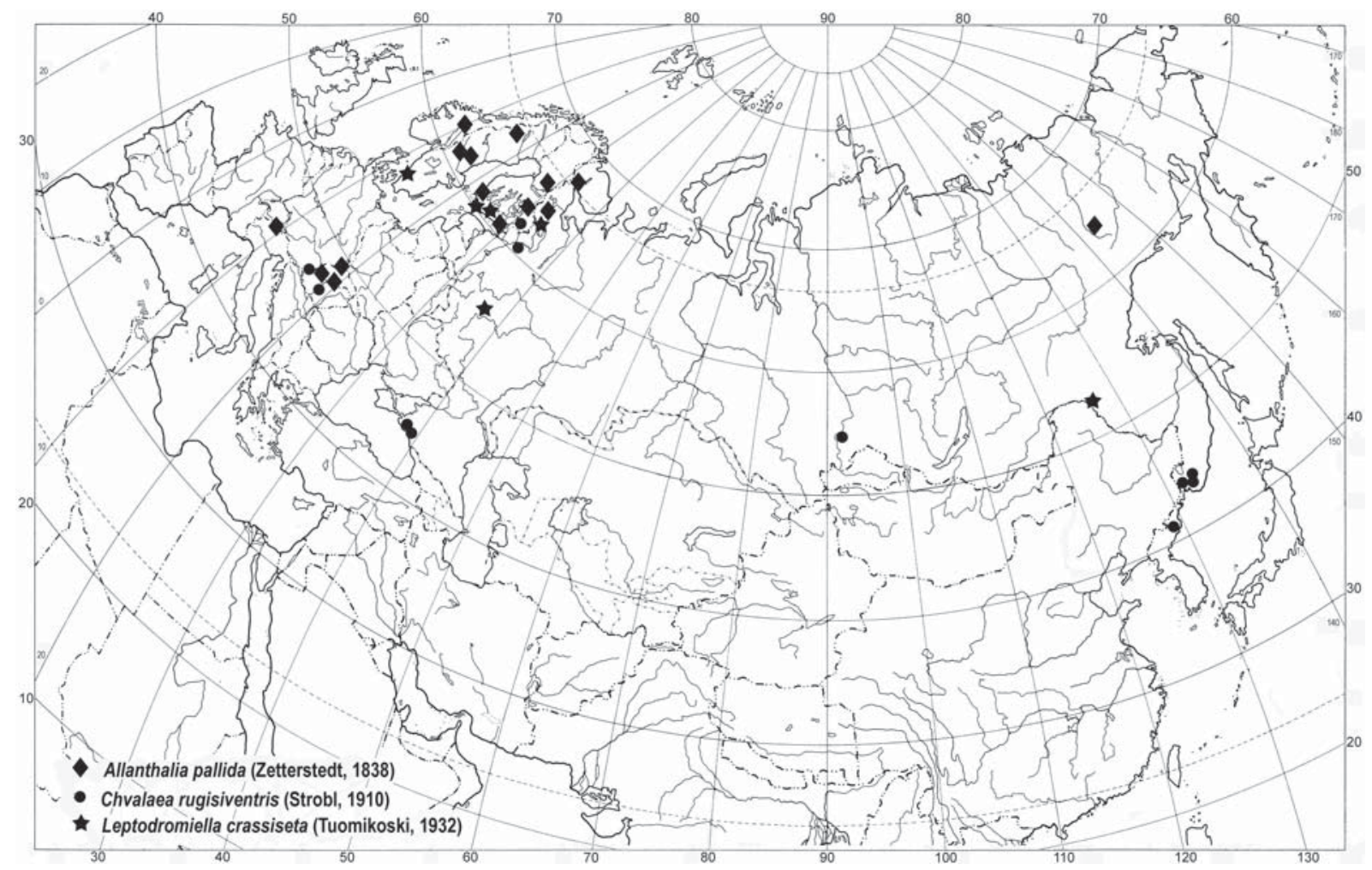

Fig. 14. Distributions of genera Allanthalia, Chvalaea and Leptodromiella in the Palaearctic Region.

Рис. 14. Распространение родов Allanthalia, Chvalaea и Leptodromiella в Палеарктическом регионе.

Papp L., Földvári M. 2002. A new genus and three new species of Hybotidae with new records of the Hungarian Empidoidea (Diptera) // Acta Zoologica Academiae Scientiarum Hungaricae. Vol.47. P.349-361.

Shamshev I.V. 2016. An annotated checklist of empidoid flies (Diptera: Empidoidea, except Dolichopodidae) of Russia // Proceedings of the Russian Entomological Society. Vol.87. P.1184.

Sinclair B.J., Cumming J.M. 2000. Revision of the genus Apterodromia (Diptera: Empidoidea), with a redefinition of the tribe
Ocydromiini // Records of the Australian Museum. Vol.52. P.161-186.

Sinclair B.J., Cumming J.M. 2006. The morphology, higher-level phylogeny and classification of the Empidoidea (Diptera) // Zootaxa. No.1180. P.1-172.

Strobl P.G. 1910. Die Dipteren von Steiermark. II. Nachtrag // Mitteilungen des Naturwissenschaftlichen Vereines für Steiermark. Bd.46 (1909). S.45-293.

Tuomikoski R. 1932. Zwei neue Empididen aus Finnland// Notulae Entomologicae. Vol.12. P.46-50. 